\title{
Experience
}

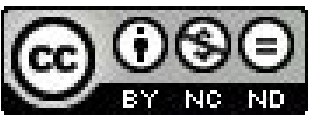

\section{Institutions of higher education and the idea of lifelong learning}

\author{
Aleksandra Marcinkiewicz \\ al.marcinkiewicz@gmail.com
}

\begin{abstract}
The idea of lifelong learning is very popular in the XXI century. This paper presents how Polish universities reflect this idea. The main theories of andragogy were compared with each other and a relationship was shown, between this concept and adult education. Moreover, it analyses the effectiveness of different management styles continuing education in Polish universities and their implications for institutions of higher education. It also describes the main programs of the European Commission to promote lifelong learning in Europe.
\end{abstract}

Keywords: lifelong learning, lifelong education, continuing education,higher education, university, adult education

Society at the turn of the twentieth century is described in the literature as a knowledge based society or an information society. The information technology revolution is believed to have created a new type of society where people have to deal with a free and unlimited flow of information. It should be noted that the civilization of the XXI century will not be a material civilization but an invisible one (Dzięgielewska 2002, p. 55). Nowadays man is a unit for seeking a fortune through knowledge and learning is an essential element of human life in an era of information (Dubas 2002, p. 15-151).

One of the pillars of the information society is knowledge. In the present reality it is not acceptable to view that a person can finish their education at some point in life. The dynamics of changes in the world today means that knowledge quickly becomes outdated, requiring constant updating. In a knowledge based society education has become a strategic factor of social development and achieving this goal is seen as lifelong learning. 
The idea of lifelong learning is a new educational reality, which should be continued for the whole of your life. This idea is based on the emerging information society. Lifelong learning is not a new idea because in 1926 Eduard Lindeman had developed the main arguments in The meaning of adult education. He believed that education should not have an end because one's whole life is an unceasing process of learning (Field 2006, p. 9). However lifelong learning is understood differently, depending on the environment.

Initially the idea of lifelong learning was regarded in the context of the working population. Development of this position was that all areas of adult education make up the idea of lifelong learning, which are clearly separated from the education of youth and family care and the environment (Półturzycki 2004a, p. 36).

Another concept emphasized the patency of the educational system. Further education was believed to be a system of continuing education, namely as vocational education, or higher and postgraduate studies (Półturzycki 2004a, p. 36).

The full concept of lifelong learning was adopted by UNESCO, according to which the essence of lifelong learning covers the whole human life and serves its development. It is also the guiding principle that indicates the direction of contemporary educational reforms on general education, vocational and higher education, but also professional work, adult education, training and education in parallel in the family and the environment. The main task of continuing education is the upbringing of a new human type which is characterized by a creative attitude and dynamic approach to life and culture. It assumes a man who will be able to improve himself, to change the living conditions and improve them for the good of society (Półturzycki 2004a, p. 36). The cited definition of lifelong learning is accepted by Polish, Scandinavian, French and American scientists, although they are still trying to identify between continuing education and further education or adult education.

The basic principle of lifelong learning is to preserve the continuity and regularity of the learning process, which seeks to ensure sustainable development. The education and development of every person should be multifaceted, not only in educational schools and higher education, but also in the system of adult education and self-education. Thus, continuing education covers the entire school system and parallel education, adult education and education in the environment. This approach significantly influenced the transformation of the educational system by introducing new goals, forms, methods and content of education (Półturzycki 2004b).

M. Malewski drew attention to "mess of definitions" in andragogy. Continuing education is often wrongly identified with lifelong learning. According to D. Korzan: lifelong 
learning is an idea whose mission is to train and educate people throughout their lives. In another approach, learning is characterized as contemporary change to the human in society and the world, improved abilities, and also all-round development of personality throughout life. Whereas, continuing education is aimed at maintaining or continuing to develop knowledge and trade skills (Korzan, 2005). In the reasons for this conceptual chaos, J. Kargul sees among others the inaccuracies in the translation of foreign texts into Polish (Kargul 2001, p. 38-40). However, this reason is not sufficient, because in the English literature also there are inconsistencies in terminology within lifelong learning (Field 2006, p. 2-3).

R. Kidd drew attention to the fact that the idea of lifelong learning was for centuries evident in the views of many well-known humanists. However, only in modern times has it become particularly interesting. It also noted the possibility of and need for achievement in educational practice. The realization of lifelong learning should integrate all forms of education and pedagogical activities, to mitigate the differences between education and training, and ensure appropriate use of leisure time. R. Kidd distinguished three dimensions of lifelong learning, which include (Cf. Półturzycki 2004a, p. 38):

- Education in length - includes consecutive levels of schooling - from nursery schools through schools to universities and postgraduate studies. The rules enable young people and adults access to education, regardless of their age, profession, place of residence and other factors that affect higher education.

- Education in width - learning a variety of areas of life, science and culture, regardless of vertical studies. There are not barriers between fields of life and culture. However, extracurricular educational institutions enable full use of this dimension by creative people.

- Education in depth - this dimension is closely linked to the quality of education - it is expressed in motivation, skills of self-education, intellectual interests, life style, which is consistent with the concept of lifelong learning, cultural and leisure use.

The cited concept broadens the understanding of lifelong learning - emphasizes the quality of education and identifies the needs and the possibility of after-school education and adult education. R. Kidd's theory is important for adult education because it combines three forms of educational activity: school education, extracurricular education and self-study. The theory does not recognize them vicariously or in opposition, but insists on the need for the educational activity in the three, above-mentioned dimensions of education. It implies an education programme in schools and universities, assisted by self-study activity and participation in extracurricular forms of adult education (Półturzycki 1994, p. 30-31). 
Education in the modern world has become an integral part of life, allowing easy function in reality. Currently, there are also opinions that lifelong learning is no longer a voluntary educational activity undertaken by a privileged part of society, but it is the compulsion and necessity, essential for the proper functioning in the modern world (Malewski 2001, p. 37). This is a reason why adult education is so important as an idea of lifelong learning. Each of the educational processes, including referring to adults must consist of three components: a student, a teacher and knowledge. One of the specific elements in adult education is a fact that adult people have personal experiences - it is a very important factor in the educational process. In addition, the educational process is undertaken by them voluntarily and knowingly. M. Malewski singled out three models of educational work with adults, which include (Malewski 2000, p. 47-63):

- The technological model - in this the teacher is the central element. It is a person who teaches an adult in an authoritarian manner. The teacher provides students with an objective picture of the world and shows them how they should live in this world. The teacher is responsible for student learning outcomes. However, the student is a passive recipient of the content transmitted by the teacher.

- The humanistic model - it assumes a partnership relationship between a student and a teacher. In this model the student is the most important element. The consequence of this relationship is the fact that the teaching program is related to the student's needs. The education should develop students comprehensively.

- The critical model - The student is completely independent of any official teaching programs and teaching contents. The student's educational activity should help to improve skills and interests which allow him to obtain a broader perspective of the world. In this model, students should think critically and reflectively. There is not a teacher in ordinary meaning but this role can be performed by various types of media. It could be said that the student learns from "real life": movies, literatures, Internet.

The typology of P. H. Coombs could be helpful in the organizing of ideas about continuing education. The author distinguished three qualitatively different areas of adult education: non-formal, informal and formal education (Malewski 2000, p. 57). Formal education is a hierarchical system of educational institutions, which through certificates and diplomas, selects students for different social roles and puts them on different levels of the social structure. Non-formal education includes educational activities, which lie outside the formal education system, which include courses, seminars, lectures, training, postgraduate studies, etc. However, 
informal education refers to processes in which the student acquires the knowledge, attitudes, values, skills from universal experience. Nowadays a change from formal education to nonformal and informal may be observed in adult education. In the new system an adult student will better and easier develop skills, giving different options for solving problems of everyday life (Kargul 2001, p. 40). This opinion seems to be right, if we compare it to the theory of spaces learning of K. Illeris. He has identified situations (spaces) in which learning takes place, namely: everyday learning, practice learning and apprenticeship, learning in schools and other educational institutions and learning in the workplace. It was noted as a fact that learning in an organized educational institutions is different from learning in the workplace or apprenticeship. The knowledge achieved in the institution (school) provides the proper functioning of the school environment, while outside it is almost useless (Illeris 2004, p. 175-202). For this reason, there is a difference between education and social reality. It should be noted that school institutions are not the one and only space in which there is a situation of learning. Whereas in other spaces learning from everyday life, practice or apprenticeship, learning in schools and other educational institutions and learning in the workplace - gives more opportunities to learn more useful and practical things. These situations correspond with cited education models and underline the importance of formal and informal education. Therefore, it is not surprising that in education there is an emphasis on those models of education.

Some dependencies can be seen by combining together all of these theories. It should be noted that areas of different theories correspond to each other and they create common spaces which are characteristic of specific learning forms. However, the compared concepts are not the same, but they have common elements and they can be classified into one group.

Table 1.

The three dimensions of lifelong learning, models of educational work with adults, areas of adult education, situations (spaces) learning - common areas

\begin{tabular}{|c|c|c|c|}
\hline $\begin{array}{c}\text { R. Kidd- } \\
\text { three dimensions of } \\
\text { lifelong learning }\end{array}$ & $\begin{array}{c}\text { M. Malewski - models of } \\
\text { educational work with } \\
\text { adults }\end{array}$ & $\begin{array}{c}\text { P. H. Coombs- } \\
\text { areas of adult education }\end{array}$ & $\begin{array}{c}\text { K. Illeris- } \\
\text { spaces of learning }\end{array}$ \\
\hline Education in length & Technological model & Formal education & $\begin{array}{c}\text { Learning in schools and } \\
\text { other educational } \\
\text { institutions }\end{array}$ \\
\hline Education in width & Humanistic model & Non-formal education & $\begin{array}{c}\text { Learning at work, practice } \\
\text { learning and } \\
\text { apprenticeship }\end{array}$ \\
\hline Education in depth & Critical model & Informal education & Everyday learning \\
\hline
\end{tabular}

Source: Author 
The relationship between different theories will be clearer when examples are used. When considering, for example, a place of higher education various theories can be seen that this form of training is located in education in length, as well as in formal learning. In addition, it is a learning space in schools and other educational institutions, and working with adult people using the technology model. Thus, considering the example of higher education it should be noted as a common area for all concepts. A similar relationship is evident in the other two areas. Different kinds of training courses are examples of learning through practice or practising. They belong to education in width, and are also a form of non-formal education and assigned to the humanistic model of work with adult people. The last case concerns the learning from everyday life (e.g. improving knowledge of the hobby), which corresponds to the critical mode. It is also education in depth from the concept of R. Kidd, and a sub-area of informal learning.

Lifelong learning is implemented in Poland by the public institutions or institutions which act on the open market under commercial law. These institutions are different in form, scope of educational activities and degrees or kinds of certificates. In Poland we can distinguish the following institutions (Kędzierska 2008, p. 6-7):

- Universities;

- Centers of continuing education;

- Centers of practical education;

- Centers for research - development;

- Schools for adults;

- Centers for training, retraining and improvement of human resources, associations, foundations, companies and others;

- Employers (HR).

Universities occupy an important place in the report of Jacques Delors, which shows the trends of education in the twenty-first century. The creators of this report, determine higher education as the engine of economic development, the goal of lifelong education and also as the depositor and the creator of knowledge and the main tool for the transmission of cultural and scientific experience which humanity has gathered (Delors 1996, p. 58). According to the report, universities are not confined to lifelong learning, but also to improve education stakeholders at the highest level, to renew the education system, work out and implement various innovations in education. The university is seen as a bridge between higher 
education from further education. Universities should create a network of centers with institutions of lifelong education and with centers for protecting and nurturing culture (Półturzycki 2004a, p. 52).

By the middle of the last century the basic functions of the university were limited to educational and research functions. In the twentieth century we are dealing with massive universities and treating them as "factory ideas" or preparation in a short time for the professions and providers of knowledge of "know-how". It is expected of them that they will play a subservient role in society. Universities are forced to compete with a wide variety of educational offers of higher vocational schools. Therefore, universities need to introduce new organizational forms, new studies, departments and modes of study. Despite adversity, universities should try to maintain the independence of research and education, which manifests itself in a general education (Kobylarek 2002, p. 94-97).

Significant changes in universities in Britain began to appear in the second half of the twentieth century. Until then, higher education was strongly separated from other forms of further adult education. Adult education (further education) appears in the 60's to have been operated independently of higher education. Since 1980, many institutions have begun to offer further training for lower level vocational demands. During the 90's in the UK we were dealing with two categories of adult education- further education (school) and higher education which in 1997 created a new category: lifelong learning (Scott 2000, p. 29).

The change in the Polish universities appeared in the late 90's. The transformation has been related to the restructuring, which gradually covered the whole academic life, research and management. Initiation of these changes was signed by four European Union countries (UK, Germany, Italy and France). The Sorbonne Declaration, which represented the concepts of harmonization of European higher education. The great potential and possibilities of this idea has also been recognized by other countries, including Poland, because a year later, 29 countries signed the so-called. Bologna Declaration, from which began the implementation of the Bologna Process. This process is unique in the world, because it is designed to harmonize universities, and not standardize them. Such a position indicates that diversity is strength in universities' development while preserving the their autonomy. The Bologna Declaration sets out the general ways of achieving these objectives, which include (Deklaracja Bolońska i co dalej. Zbiór komunikatów, wytycznych i sugestii. Materiały ze strony MENiS 2004, http://www.uka.amu.edu.pl/pictures/bolonia.pdf, p. 2-3):

- Establish a system of comparable degrees;

- Introduction of 2 and 3 levels of studies; 
- Introduction of a point system to describe a student's achievement - ECTS;

- Implementation of student and staff mobility in Europe;

- Working together to ensure the quality of education.

The Communication of Paris was signed in 2001, which complemented the Bologna Declaration. This document has been postulated to introduce the idea of lifelong learning in universities, the cooperation and collaboration of universities, staff and students in the Bologna Process. All these documents constitute the complete guidelines and modernization of the European Higher Education Area. On the aspect of lifelong learning we can also point out other acts, such as a message from the meeting of European Ministers responsible for Higher Education: Towards a European area of higher education, signed in 2001 (http://www.ond.vlaanderen.be/hogeronderwijs/bologna/documents/MDC/PRAGUE_COMM UNIQUE.pdf).

Introducing the idea of lifelong education for higher education, refers to the quality and efficiency level of education, the extension of learning using new technology. It is also promotes man's development and increasing participation in social life, providing easier access to higher education, and cooperation between universities and the local community and business (Groenwald 2004, p. 126). This process implies the introduction of new objectives, forms, methods and content of education. Accordingly, in addition to the traditional functions (teaching), universities must pursue new functions, such as realization of the idea of lifelong learning and improving international cooperation, preparing and conducting research, developing specialized training (Półturzycki 2004a, p. 52).

With the advent of lifelong learning, the model of university education has expanded to extramural studies, which are similar to stationary studies, possibly with post-graduate studies. Currently, colleges and universities have expanded the forms of education courses and training, not only at university level (Wiśniewski 2008). An interesting idea is an open learning institution also called an Open University. This form seems to be the best example, which shows the idea of lifelong learning in higher education. These universities are for anyone who wants to take up sciences, regardless of their previous education and formal qualifications. This solution aims at the needs of people who could not begin higher education or continue it. There are very popular methods of distance education, e. g. television, radio, computer technology, films and other (Półturzycki 2004a, p. 40).

It should be said that higher education in Poland had an exclusive character until 1989. There are not enough universities, recruitment has limited access to this form of education. 
Universities had to face the realities of the capitalist world, so they should have met the expectations of students (customers) and labor market (Kurantowicz 2007, p. 112-113). It was necessary to adapt the educational offer to the new reality. Adapting curriculum to the needs of students should include the following cycle of activities: knowledge of environment, defining the market characteristics, assessing the potential labor market and assessing the possibility of its own infrastructure and strategic priorities. The result of these actions should: determine the number of people interested in education and their educational needs, term structure of the group and diagnosis of knowledge areas. The next step is to adapt a continuing education program based on the results expressed as a list of needs, which include: staff, technical resources and the necessary investments. Unfortunately, the structure of higher education in Poland did not provide monitoring of the economic situation and the labor market (Wiśniewski 2008).

The European Commission has initiated a number of interesting education programs such as the Socrates project. The first phase of this program was implemented in 1995-1999 and the second phase in 2000-2006. It consisted of several components, covering different areas and levels of education. Adult learning, including lifelong learning are covered by the Grundtvig programme, which functioned as part of Socrates II to 2006/07 (Marciszewska, Zbierzchowska 2006, s. 43-48). The next program called Lifelong Learning was implemented in 2007 and consists of four pillars, which include Grundtvig. The program should achieve the following objectives:

- To improve the quality and accessibility of mobility throughout Europe of people involved in adult education and to increase its volume;

- To improve the quality and to increase the volume of cooperation between organizations involved in adult education throughout Europe;

- To assist people from vulnerable social groups and in marginal social contexts, in particular older people and those who have left education without basic qualifications, in order to give them alternative opportunities to access adult education;

- To facilitate the development of innovative practices in adult education and their transfer, including from a participating country to others;

- To support the development of innovative ICT-based content, services, pedagogies and practice for lifelong learning;

- To improve pedagogical approaches and the management of adult education organizations (http://grundtvig.org.pl/index.php/ida/2/). 
Undeniably, continuing education is an integral part of universities. Therefore, selecting the right system management of lifelong learning essentially affects the quality of education. The management system in Polish universities is different from that in force in most European countries. Z. Wiśniewski in the article: Kształcenie ustawiczne-centralne czy niezależne? (Lifelong learning-central or independent?) compared the organization and university management of continuing education in Poland with other methods used in European Union countries and then analyzed the effectiveness of both systems (Wiśniewski 2006). In Poland, the predominant system is based on the independent faculties. Such a location system of lifelong learning is the result of independent work of departments and faculties. The management scheme of lifelong learning for faculty includes:

- Pro-Dean to extramural studies, who usually constitutes a "decision centre";

- Dean's office employees who carry out activities related to registration, record the progress of students, control of deposits and others;

- One/ some teaching staff who deal with planning, locations and time schedule;

- The employee who leads a registration deposit;

- Department of education university where there are supervising the training course for non-stationary department, but also record information received from the Deans.

The above management scheme of lifelong learning implies the need to devote more time to coordinate the organization of labor between cells. The result is an overload of a small number of administrative responsibilities associated with lifelong learning. A small group of employees cannot focus on strategic activities, planning and analyzing the quality of the studies, because it is focused on current operations, which take up the bulk of their time. Therefore, these tasks fall on the teaching staff.

In countries of the European Union and many Polish non-public higher education schools learning is carried out in specific centers, located in the structure of the university. This solution helps with better organization of work and dedication of more time to strategic activities, planning and analysis of the quality of education, creating a database of technical and efficient disposition of the funds. Important for the assessment of academic learning was a report from the conference: Edukacja ustawiczna a szkoty wyższe w XXI wieku [Continuing education and higher education in the XXI century], published in 1998 (Frąckowiak 2004, 
p. 263). The report highlights the changes that must take place at the university for it to become an institution of learning throughout life. These changes concern:

- A more flexible approach to the conditions of admissions;

- The development of distance education;

- Education methods;

- Create a system which will accept the experience from informal education;

- Ways of support for students;

- The cooperation of universities with the local community.

The major conclusion emerging from the report is such that higher education institutions should follow the above indications, if they do not want to be marginalized in the education market. It should be noted that universities are seeking various opportunities to meet aspirations of adults to acquire knowledge. When adults face obstacles in the form of unrealistically high expectations of recruitment to study, they look for other opportunities that are free from such barriers, and knowledge is passed on in a more attractive way. This is proof of the strong correlation between education with economy and market.

The website of University of Wroclaw was analyzed in order to examine the manner and extent of realization lifelong learning. It is a fact that the structure of universities does not include any unit in charge of continuing education. According to the forms of continuing education it offers a certain part of a wide range of graduate studies and the University of the Third Age open lectures, science clubs, conferences and lectures and activities of the university careers service.

One of the most significant developments in the field of continuing education at the tertiary level is a move towards the needs and expectations of people who wants to develop and educate. Nevertheless, if universities seeking to fill a new role (continuing education), they should not lose their educational and research functions, which are fundamental, because they constitute the essence of those institutions. According to the concept of lifelong learning access to education should be equal irrespective of education. An example is the University of The Third Age, which also allows participation in classes for people without higher education. Universities reflect the ideas of lifelong learning in improving the quality and effectiveness of education, expanding educational opportunities, which uses new techniques and cooperating between the institutions of higher education and the local environment. The idea of lowering the recruitment requirements at universities is controversial, because it threatens a significant 
decrease in the level of university education. Problematic also is the assessment of knowledge obtained in informal and non-formal education, because these are areas difficult to measure and assess. Without a doubt, a lot of benefits for academic learning come from participation in university education programs offered by the European Union. Despite the many issues that universities must meet to make the best reflection of the lifelong learning, they are an important element of that idea. The university is seen as a factor determining the direction of the idea of lifelong learning, because it has potential, which helps with realization of this concept.

\section{Bibliography}

Ciechanowska D. (2004), Od edukacji ustawicznej do całożyciowego uczenia się - potrzeba kształcenia kompetencji uczynienia się, [in:] Góralska R., Półturzycki J. (eds.), Edukacja ustawiczna w szkołach wyższych-od idei do praktyki, Wydawnictwo ITE, Płock- Toruń

Delors J. (ed.) (1996), Learning: the treasure within. Report to UNESCO of the International Commission on Education for the Twenty-first Century,UNESCO, Paris.

Dubas E. (2002), Dorosłość w erze informatycznej a zadania edukacji (dorostych), [in:] Wesołowska E. A. (ed.), Edukacja dorostych $w$ erze globalizmu, Biblioteka Edukacji Dorosłych, Płock.

Dzięgielewska M. (2002), Człowiek dorosły w społeczeństwie informatycznym, [in:] Wesołowska E. A. (ed.), Edukacja dorostych $w$ erze globalizmu, Biblioteka Edukacji Dorosłych, Płock.

Field J. (2006), Lifelong learning and the new educational order, Trentham Press, Stock on Trent.

Field J., Leicester M. (eds.) (2000), Lifelong Learning. Education Across the Lifespan, Routledge Falmer, London.

Frąckowiak A. (2004), Edukacja ustawiczna a szkoły wyższe w XXI wieku, [in:] Góralska R., Półturzycki J. (eds.), Edukacja ustawiczna $w$ szkołach wyższych- od idei do praktyki, Wydawnictwo ITE, Płock- Toruń.

Góralska R., Półturzycki J. (eds.) (2004), Edukacja ustawiczna w szkołach wyższych-od idei do praktyki, Wydawnictwo ITE, Płock- Toruń.

Groenwald M. (2004), Edukacja przez całe życie- od idei do praktycznych rozwiazań, [in:] Góralska R., Półturzycki J. (eds.), Edukacja ustawiczna w szkołach wyższych-od idei do praktyki, Wydawnictwo ITE, Płock- Toruń. 
Illeris K. (2004), The three dimensions of learning: contemporary learning theory in the tension field between the cognitive, the emotional and the social, Roskilde University Press, Leicester.

Kargul J. (2001), Obszary pozaformalnej i nieformalnej edukacji dorostych. Przesłanki do budowania teorii edukacji całożyciowe, Wydawnictwo Naukowe DSWE, Wrocław.

Kidd R. J. (1966), The Implications of Continuous Learning, Gage, Toronto.

Kobylarek A. (2002), Uniwersytet - zarys ewolucji idei podstawowej, „Nauka i Szkolnictwo Wyższe" 1.

Kurantowicz E. (2007), O uczqcych się spotecznościach. Wybrane praktyki edukacyjne ludzi dorostych, Wydawnictwo Naukowe DSWE TWP, Wrocław.

Malewski M. (2000), Modele pracy edukacyjnej z ludźmi dorostymi, „Teraźniejszość Człowiek - Edukacja" 9.

Malewski M. (2001), Edukacja dorostych w pojęciowym zgiełku. Próba rekonstrukcji zmieniajacej się racjonalności andragogiki, „Teraźniejszość - Człowiek - Edukacja” 2.

Półturzycki J. (2004a), Szkolnictwo wyższe a idea edukacji ustawicznej, [in:] Góralska R., Półturzycki J. (eds.) (2004), Edukacja ustawiczna w szkołach wyższych-od idei do praktyki, Wydawnictwo ITE, Płock- Torun.

Scott P. (2000), The death of mass higher education and the birth of liflong learning, [in:] Field J., Leicester M., (eds.), Lifleong Learning. Education Across the Lifespan, Routledge Falmer, London.

Wesołowska E. A. (ed.) (2002), Edukacja dorostych w erze globalizmu, Biblioteka Edukacji Dorosłych, Płock.

Wołk Z. (2009), Wstęp, [in:] Wołk Z. (ed.), Szkolnictwo wyższe w systemie ksztatcenia ustawicznego, Oficyna Wydawnicza Uniwersytetu Zielonogórskiego, Zielona Góra.

Wołk Z. (ed.) (2009), Szkolnictwo wyższe w systemie kształcenia ustawicznego, Oficyna Wydawnicza Uniwersytetu Zielonogórskiego, Zielona Góra.

\section{Netography}

Deklaracja Bolońska i co dalej. Zbiór komunikatów, wytycznych i sugestii. Materiały ze strony MENiS 2004, http://www.uka.amu.edu.pl/pictures/bolonia.pdf, retrieved: 20.05.2010. http://grundtvig.org.pl/index.php/ida/2/, retrieved: 23.05.2010.

Kędzierska B. (2008), Kształcenie ustawiczne jako priorytetowa koncepcja wszystkich krajów europejskich, http://www.up.krakow.pl/ecemi/file/Kszt_Ust_podstawy.pdf, retrieved: 20.05.2010. 
Korzan D. (2005), W poszukiwaniu istoty edukacji permanentnej, “e-mentor" 2(09), http://www.e-mentor.edu.pl/artykul_v2.php?numer=9\&id=146, retrieved: 10.05.2010.

Marciszewska E., Zbierzchowska A. (2006), Kształcenie ustawiczne na uniwersytetach. Projekty EQUIPE $i$ EQUIPE PLUS, “e-mentor” 4(16), http://www.ementor.edu.pl/artykul/index/numer/16/id/334, retrieved: 23.05.2010.

Mikołajczyk K., Kształcenie ustawiczne- od koncepcji do praktyki, www.cren.pl/CRENSGH_15_KU_2007.pfd, retrieved: 09.05.2010.

Półturzycki J. (2004b), Źródła i tendencje rozwojowe edukacji ustawicznej, "e-mentor" 5(7), http://www.e-mentor.edu.pl/artykul_v2.php?numer=7\&id=97, retrieved: 10.05.2010.

Półturzycki J. (2006), Aktualność problemów edukacji ustawicznej, "e-mentor" 1(13), http://www.e-mentor.edu.p1/artykul_v2.php?numer=13\&id=244, retrieved: 23.05.2010.

Towards a European area of higher education: Communiqué of the meeting of European Ministers in charge of Higher Education in Prague on May $19^{\text {th }} 2001$ (2001), http: //www.ond.vlaanderen.be/hogeronderwijs/bologna/documents/MDC/PRAGUE_COMMUNI QUE.pdf, retrieved: 11.12.2010.

Wiśniewski Z. (2006), Ksztatcenie ustawiczne- centralne czy niezależne?, „e- mentor” 4(16), http://www.e-mentor.edu.pl/artykul_v2.php?numer=16\&id=337, retrieved: 23.05.2010.

Wiśniewski Z. (2008), Rola uczelni w kształceniu ustawicznym w społeczeństwie na przykładzie potrzeb edukacyjnych osób powyżej 50 roku życia, "e-mentor" 4(26), http://www.e-mentor.edu.pl/artykul_v2.php?numer=26\&id=568, retrieved: 20.05.2010. 